\title{
Research Article: Heritability studies in tomato (Solanum lycopersicum L.) for growth, yield and quality
}

Article Chronicle: Received : 10.07.2017; Accepted : 25.07.2017

KEY Words: Tomato, Heritability, Genetic advance

Author for correspondence :

\section{RAMANA}

SSPG Horticulture

Polytechnic,

Madakasira,

ANANTHAPURAM (A.P.)

INDIA

Email : hortirams@

yahoo.co.in

See end of the article for authors' affiliations
SUMMARY : The present investigation to estimate and asses the genetic components of variation i.e. genotypic and phenotypic variation, heritability and genetic advance in tomato (Solanum lycopersicum L)." for yield and quality was carried out during at Vegetable Research Station, Rajendranagar, Hyderabad to study the genetic parameters in this ten parents (EC-165749, EC-157568, EC-164838, LE-56, LE-62, LE64, LE-65, LE-66, LE-67 and LE-68) were crossed in diallele mating design (without reciprocals). The resultant $45 \mathrm{~F}_{1}$ 's were evaluated along with their parents and two standard checks (Siri and US-618). The genetic variability studies indicated that high estimates of PCV and GCV were obtained for plant height, number of fruits per cluster, average fruit weight, fruit yield per plant, number of locules per fruit, pericarp thickness, ascorbic acid and lycopene content indicated a good deal of variability in those characters signifying the effectiveness of selection of desirable types for improvement. High heritability with high genetic advance as per cent of mean was observed for plant height, number of primary branches per plant, number of fruits per cluster, fruit length, average fruit weight, fruit yield per plant, number of locules per fruit, pericarp thickness, titrable acidity, ascorbic acid content, total sugars and lycopene content. Hence, simple selection based on phenotypic performance of these traits would be more effective.

How to cite this article : Ramana, V., Srihari, D., Reddy, R.V.S.K., Sujatha, M. and Bhave, M.H.V. (2017). Heritability studies in tomato (Solanum lycopersicum L.) for growth, yield and quality. Agric. Update, 12(TECHSEAR-3) : 617-621; DOI: 10.15740/HAS/AU/12.TECHSEAR(3)2017/617-621. 